\title{
Analysis of soil effects as leachate filter: A case study of TPA Mandung Tabanan
}

\author{
Kadek Diana Harmayani ${ }^{1 *}$, I Nyoman Ari Budiman ${ }^{1}$, and Luh Putu M. Karunia Putri ${ }^{1}$ \\ ${ }^{1}$ Department Civil Engineering, Universitas Udayana, Bali, Indonesia
}

\begin{abstract}
The accumulation in large volume of solid waste in the area of TPA Mandung is creating a new serious problem since the leachate is extremely increasing. The spill drastically contaminates the groundwater and the surrounding environment because the wastewater treatment plant isn't working on full capacity. Based on those facts, it is necessary to start researching on how the leachate influences the soil characteristics, and how to get the soil to provide a proper filtration. The samples of soil and the leachate from TPA Mandung have, at first, been collected; soil properties have been physically and mechanically tested, while the leachate characteristics have been determined from the parameters of the contained substances. The leachate filtration was performed simultaneously with a hydraulic conductivity test simply varying its height from $7 \mathrm{~cm}, 9 \mathrm{~cm}$, and $11 \mathrm{~cm}$. The water drained from the hydraulic conductivity test has been reexamined to determine the changes in the leachate parameters after passing through the soil. The $\mathrm{K}$ value (hydraulic conductivity coefficient) in the soil hydraulic conductivity test sampled with height $11 \mathrm{~cm}, 9 \mathrm{~cm}, 7 \mathrm{~cm}$, were respectively $0.000050 \mathrm{~cm} / \mathrm{sec}, 0.000062 \mathrm{~cm} / \mathrm{sec}$, and 0.000065 $\mathrm{cm} / \mathrm{sec}$. The results showed a decrease in the coefficient of hydraulic conductivity along with the addition of leachate and the variation in sample height. The leachate in TPA Mandung before and after filtration had COD, BOD5, TSS, TDS and oil levels that exceeded the permitted threshold according to Regulation of Minister of Environment No. 5 of 2014 concerning Wastewater Quality Standard.
\end{abstract}

\section{Introduction}

The accumulation of solid waste in the TPA Mandung with large volumes creates a new problem which is called leachate. In general, the leachate can have some impacts such as the impact on the life of aquatic biota, groundwater quality, health, and environmental aesthetics. The high content of $\mathrm{BOD}_{5}$ (Biological Oxygen Demand) in the leachate can cause potential contamination for both surface and groundwater [1,2].

According to Government Regulation of the Republic Indonesia No. 82 year 2001 about Water Quality Management and Water Pollution Control, the leachate treatment business must use wastewater management installation or Instalasi Pengelolaan Air Limbah or IPAL. TPA Mandung has had IPAL, but it has not operated optimally yet. The leachate

${ }^{*}$ Corresponding author: kdharmayani@yahoo.com 
which enters the IPAL is not well-processed. On September $1^{\text {st }}, 2016$, Sumur Pantau II produced wastewater with $221 \mathrm{mg} / \mathrm{L}$ of $\mathrm{COD}$ and $109 \mathrm{mg} / \mathrm{L}$ of $\mathrm{BOD}_{5}$. The rate of both $\mathrm{COD}$ and $\mathrm{BOD}_{5}$ have exceeded the quality standard based on the Ministry of Environment Regulation No 5 year 2014 about the Standard of Wastewater Quality. This exessive value of $\mathrm{COD}$ and $\mathrm{BOD}_{5}$ is very harmful to the environment.

The generated leachate will slowly seep into the underlying soil layer, which will also raise the risk of contamination of groundwater. Potential contamination of the leachate in groundwater is hazardous considering groundwater is the source of raw water for the survival of living creatures. One of the efforts that can be done to maintain groundwater quality is by knowing the potential of the soil as a natural filter. The soils, especially clay, have many uses such as oil purifiers (clove oil), and also as an alternative to solve waste problems, especially heavy metals [3]. Based on this matter, the research about the influence of the leachate towards the soil characteristics and soil potential as a natural filter is necessary.

\section{Literature review}

\subsection{The classification of soil}

There are two systems that commonly used to classify the soil, namely the Unified Soil Classification System and AASHTO (American Association of State Highways and Transportation Officials). Both systems use simple soil index properties such as grain size distribution, liquid limit, and plasticity index [4].

\subsection{The soil physical characteristics}

The physical characteristics of the soil can be known from the texture, structure, consistency, color, temperature, drainage and the aeration of the soil. The determination of soil texture can be done qualitatively (in the field) and quantitatively (in the laboratory) [5].

\subsection{The soil mechanical characteristics}

The soil characteristics are the characteristics that may change after additional forces are added to the soil or through a loading process aimed at improving soil properties [6].

\subsection{The leachate}

The leachate occurs due to the mixing of rainwater (both through the infiltration process and percolation process) with the trash that has been decomposed which contains very fine suspended substances and pathogenic microbes. The leachate can cause potential contamination for surface- and groundwater. This is due to the high content of $\mathrm{BOD}_{5}$ which is about $3.500 \mathrm{mg} / \mathrm{L} \mathrm{[7]}$.

\subsection{The parameters of the leachate}

The leachate quality parameters are based on three main properties, namely physical properties, chemical properties, and microbiological properties. Of these three main parameters, in accordance with Peraturan Menteri Lingkungan Hidup No. 5, 2014 concerning Wastewater Quality Standards, The Class I Quality Standard is issued to 
regulate the threshold content of certain substances permitted. The limit of the leachate content that can still be tolerated is listed in Table 1 as follows:

Table 1. Wastewater quality standard

\begin{tabular}{|c|c|c|c|}
\hline \multirow{2}{*}{ Parameters } & \multirow{2}{*}{ Unit } & \multicolumn{2}{|c|}{ Group } \\
\cline { 3 - 4 } & & I & II \\
\hline Temperature & ${ }^{\circ} \mathrm{C}$ & 38 & 40 \\
\hline $\mathrm{TDS}$ & $\mathrm{mg} / \mathrm{L}$ & 2000 & 4000 \\
\hline $\mathrm{TSS}$ & $\mathrm{mg} / \mathrm{L}$ & 200 & 400 \\
\hline $\mathrm{pH}$ & - & $6.0-9.0$ & $6.0-9.0$ \\
\hline $\mathrm{BOD} 5$ & $\mathrm{mg} / \mathrm{L}$ & 50 & 150 \\
\hline $\mathrm{COD}$ & $\mathrm{mg} / \mathrm{L}$ & 100 & 300 \\
\hline Oils & $\mathrm{mg} / \mathrm{L}$ & 10 & 20 \\
\hline
\end{tabular}

\section{Methodology}

Soil samples were taken from the TPA Mandung are undisturbed and disturbed samples, where the samples are examined for their physical properties and mechanical properties with various related tests carried out in the soil laboratory. Tests on the undisturbed sample includes water content test and unconfined compression test, meanwhile tests on the disturbed sample includes water content, sieve analysis and hydrometer test, Atterberg limit test, compaction test, unconfined compression test, and hydraulic conductivity test. In the proctor compaction test, the test was carried out by adding $100 \mathrm{ml}$ of water and $100 \mathrm{ml}$ of leachate separately. The soil sample in the unconfined compression test comes from the compaction test with a mixture of $100 \mathrm{ml}$ of leachate, where the sample has been remolded.

In the hydraulic conductivity test, remolded soil is used as the results of the compaction test, where the soil specimen has a sample height of $70 \mathrm{~mm}, 90 \mathrm{~mm}$, and $110 \mathrm{~mm}$. Soil stability was tested using water and leachate, where the water and the leachate were dropped from a hose with a height of $600 \mathrm{~mm}$ with the test time of 48 hours for each sample and three times repetition. Leachate that passes through the soil is considered to be filtered by soil then collected in a container and tested for the solute content in the Analytical Chemistry laboratory. Leachate samples are also taken from the TPA Mandung, then placed in a glass container with a temperature of $-4^{\circ} \mathrm{C}$. The solute content of Leachate was tested then compared with leachate filtration result in a hydraulic conductivity test with a soil sample height of $70 \mathrm{~mm}, 90 \mathrm{~mm}$ and $110 \mathrm{~mm}$.

\section{Results and discussion}

\subsection{Soils in TPA Mandung}

The soil in TPA Mandung is tested physically and mechanically for knowing the properties of the soils. The result of groundwater level test shows that the soil in TPA Mandung has a water content of $37.45 \%$ for disturbed soil samples and $39.76 \%$ for undisturbed soil 
samples. The grain size of soil particles is determined by wet sieve analysis. In this test, the size of the sieve is sequenced from No. 4 to No. 200. The soil that passes the sieve No. 200 and detained in PAN will be tested again using the hydrometer analysis. Table 2 shows the percentage of the passed soil of the sieve which is then translated visually into Fig. 1 as follows.

Table 2. Result of sieve analysis.

\begin{tabular}{|c|c|c|c|}
\hline \multicolumn{2}{|c|}{ Size of sieve } & \multicolumn{2}{c|}{ Percentage (\%) } \\
\hline Inch & mm & Detained & Passed \\
\hline$\# 4$ & 4.75 & 0 & 100 \\
\hline$\# 10$ & 2 & 0.4 & 99.60 \\
\hline$\# 20$ & 0.85 & 2.68 & 96.92 \\
\hline$\# 40$ & 0.425 & 6.64 & 90.28 \\
\hline$\# 60$ & 0.25 & 6.1 & 84.18 \\
\hline$\# 80$ & 0.18 & 4.84 & 79.34 \\
\hline$\# 100$ & 0.15 & 1.74 & 77.60 \\
\hline$\# 200$ & 0.075 & 4.46 & 73.14 \\
\hline PAN & & 73.14 & 0 \\
\hline
\end{tabular}

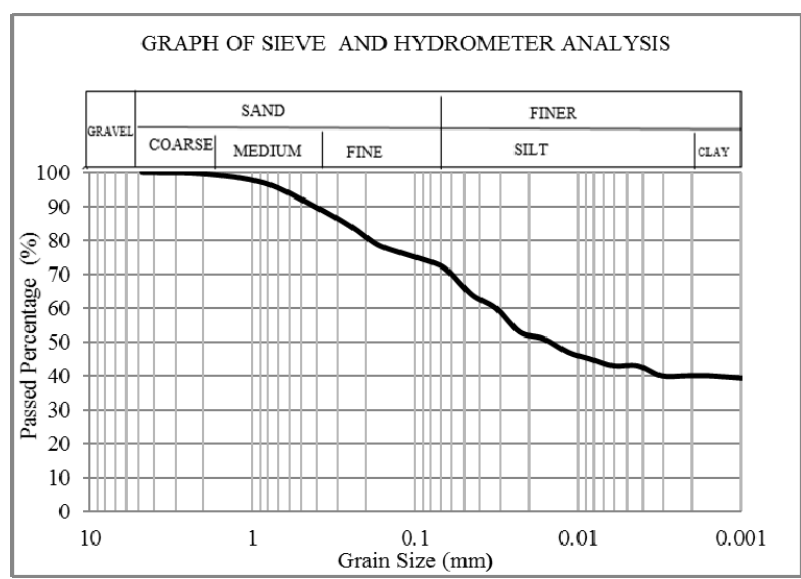

Fig. 1 Graph of sieve and hydrometer analysis.

The results of the sieve and hydrometer analysis plot described in Fig. 1 above shows that the soil in the TPA according to the AASHTO and USCS methods of soil is categorized as clay. The test of specific gravity indicates that the soil in TPA Mandung has a specific gravity of 2.7. This soil is considered as inorganic clay which commonly has a specific gravity of 2.68 to 2.75 .

According to Atterberg limits, $27.75 \%$ of the shrinkage limit (Ws) has the smallest percentage. The plastic limit (Wp) with $29.65 \%$ has less percentage than the liquid limit and is higher than the shrinkage limit. The liquid limit (Wc) of $45.87 \%$ has the highest percentage $(\mathrm{Ws}<\mathrm{Wp}<\mathrm{Wc})$. The soil compaction test shows that the soil increases dry 
density. The dry weight of $1.22 \mathrm{gram} / \mathrm{cm}^{3}$ with the optimum moisture content of $27.91 \%$ in $0 \%$ leachate has been increased to $1.44 \mathrm{gram} / \mathrm{cm}^{3}$ in $100 \%$ leachate with an optimum water content of $19.02 \%$. The test soil samples used here are test soil samples with different sample heights, where the density of the soil is ascertained to be the same one to another. The results of this test can be seen in Table 3 and Table 4 as follows.

Table 3. Hydraulic conductivity test results without leachate.

\begin{tabular}{|c|c|c|c|c|c|}
\hline \multirow{2}{*}{$\begin{array}{c}\text { Height of } \\
\text { samples } \\
(\mathrm{cm})\end{array}$} & \multirow{2}{*}{$\begin{array}{c}\text { Percentage } \\
\text { of leachate } \\
(\%)\end{array}$} & \multicolumn{3}{|c|}{ Hydraulic Conductivity Coefficient $(\mathrm{cm} / \mathrm{sec})$} & \multirow{2}{*}{$\begin{array}{l}\text { Average } \\
(\mathrm{cm} / \mathrm{sec})\end{array}$} \\
\hline & & $\mathbf{I}$ & II & III & \\
\hline 11 & 0 & 0.000095 & 0.000102 & 0.000095 & 0.000102 \\
\hline 9 & 0 & 0.000107 & 0.000120 & 0.000113 & 0.000113 \\
\hline 7 & 0 & 0.000109 & 0.000126 & 0.000120 & 0.000118 \\
\hline
\end{tabular}

Table 4. Hydraulic conductivity test results with leachate.

\begin{tabular}{|c|c|c|c|c|c|}
\hline \multirow{2}{*}{$\begin{array}{l}\text { Height of } \\
\text { samples } \\
(\mathrm{cm})\end{array}$} & \multirow{2}{*}{$\begin{array}{c}\text { Percentage of } \\
\text { leachate } \\
(\%)\end{array}$} & \multicolumn{3}{|c|}{ Hydraulic Conductivity Coefficient $(\mathrm{cm} / \mathrm{sec})$} & \multirow{2}{*}{$\begin{array}{l}\text { Average } \\
\text { (cm/sec) }\end{array}$} \\
\hline & & $\mathbf{I}$ & II & III & \\
\hline 11 & 100 & 0.000044 & 0.000056 & 0.000050 & 0.000050 \\
\hline 9 & 100 & 0.000056 & 0.000061 & 0.000067 & 0.000061 \\
\hline 7 & 100 & 0.000060 & 0.000065 & 0.000069 & 0.000065 \\
\hline
\end{tabular}

The results of the test show that the ability of the soil hydraulic conductivity tends to decrease along with the addition of sample height and leachate. The decrease of absorbing ability in the water is because the soil in the TPA Mandung has high plasticity properties, which makes the soil absorb water easily but difficult to release it. The content of the elements in the leachate like oil also affects the ability of the soil to absorb the leachate.

The qu value is obtained $0.682 \mathrm{~kg} / \mathrm{cm}^{2}$ with $\mathrm{C}$ equal to $0.341 \mathrm{~kg} / \mathrm{cm}^{2}$ from the unconfined compression test on undisturbed soil sample, while the results of the unconfined compression test which has been contaminated by $100 \%$ leachate produces qu with the value of $0.598 \mathrm{~kg} / \mathrm{cm}^{2}$ and $\mathrm{C}$ value of $0.299 \mathrm{~kg} / \mathrm{cm}^{2}$. This is because the content of certain elements in the leachate can smooth the pore of the clay well so that the cohesion on the ground is increased.

\subsection{Characteristics of leachate in TPA Mandung}

The determination of quality standard for leachate is based on Peraturan Menteri Lingkungan Hidup No. 5, 2014 about the Standard of Wastewater Quality. The results of the wastewater parameter tests can be seen in Table 5 which then will be compared with the result of parameters test of the leachate post-filtration by soil with a difference of height 11 $\mathrm{cm}, 9 \mathrm{~cm}$, and $7 \mathrm{~cm}$ in Table 6 .

The test results before and after filtration show that the soil can press the parameters such as $\mathrm{BOD}_{5}, \mathrm{COD}$, TSS, and oil well without any helps from other substances. The TDS value increases because the filtered leachate was left for 2-3 days without any treatments which cause the changes on TDS's particle. In comparison with the table of Peraturan 
Menteri Lingkungan Hidup No. 5, 2014 Concerning the Quality Standards of Wastewater, this indicates that the water content in TPA Mandung before and after filtration has exceeded the level of permitted limit. The leachate should go through some processes before it can be discharged to the ground or a river.

Tabel 5. Test result of leachate content.

\begin{tabular}{|c|c|c|c|}
\hline Parameter & Method & Unit & Result \\
\hline DO & Titrimetry & $\mathrm{mg} / \mathrm{L}$ & 0 \\
\hline BOD $_{5}$ & Titrimetry & $\mathrm{mg} / \mathrm{L}$ & 1890 \\
\hline COD & Titrimetry & $\mathrm{mg} / \mathrm{L}$ & 2606.25 \\
\hline TSS & Gravimetric & $\mathrm{mg} / \mathrm{L}$ & 1361.11 \\
\hline TDS & Gravimetric & $\mathrm{mg} / \mathrm{L}$ & 9270 \\
\hline Oil & Gravimetric & $\mathrm{mg} / \mathrm{L}$ & 350 \\
\hline
\end{tabular}

Tabel 6. Test result of post-filtration leachate content.

\begin{tabular}{|c|c|c|c|c|c|}
\hline \multirow{2}{*}{ Parameter } & \multirow{2}{*}{ Method } & \multirow{2}{*}{ Unit } & \multicolumn{3}{|c|}{ Result } \\
\cline { 4 - 6 } & & & $\mathbf{7} \mathbf{c m}$ & $\mathbf{9} \mathbf{c m}$ & $\mathbf{1 1} \mathbf{~ c m}$ \\
\hline DO & Titrimetry & $\mathrm{mg} / \mathrm{L}$ & 0 & 0 & 0 \\
\hline BOD 5 & Titrimetry & $\mathrm{mg} / \mathrm{L}$ & 637.58 & 728.49 & 545.25 \\
\hline COD & Titrimetry & $\mathrm{mg} / \mathrm{L}$ & 1689.12 & 1939.36 & 1564.10 \\
\hline TSS & Gravimetric & $\mathrm{mg} / \mathrm{L}$ & 179.26 & 149.61 & 139.82 \\
\hline TDS & Gravimetric & $\mathrm{mg} / \mathrm{L}$ & 12500 & 10920 & 10110 \\
\hline Oil & Gravimetric & $\mathrm{mg} / \mathrm{L}$ & 350 & 350 & 340 \\
\hline
\end{tabular}

\subsection{The characteristics of leachate after soil filtration and its effect on the the soil in TPA Mandung Tabanan}

The coefficient value of Hydraulic Conductivity (K) for soil with the sample height of 11 $\mathrm{cm}, 9 \mathrm{~cm}$, and $7 \mathrm{~cm}$ which is watered by leachate is $0.000050 \mathrm{~cm} / \mathrm{sec}, 0.000061 \mathrm{~cm} / \mathrm{sec}$, and $0.000065 \mathrm{~cm} / \mathrm{sec}$. The weight value of the maximum dry volume on the soil in the compaction is 1.44 grams $/ \mathrm{cm}^{3}$ with the optimum water content of $19.02 \%$. The value of qu on unconfined compression test is $0.598 \mathrm{~kg} / \mathrm{cm}^{2}$ while the value of $\mathrm{C}$ is $0.299 \mathrm{~kg} / \mathrm{cm}^{2}$ after contamination with $100 \%$ leachate.

The parameter of the leachate after the soil filtration changed with each parameter value as follows:

1. In the filtration of soil samples with the height of $7 \mathrm{~cm}$, the result obtained: DO levels of $0 \mathrm{mg} / \mathrm{L}, \mathrm{BOD}_{5}$ levels of $637.58 \mathrm{mg} / \mathrm{L}$, COD levels of $1689.12 \mathrm{mg} / \mathrm{L}$, TSS levels of $179.26 \mathrm{mg} / \mathrm{L}$, TDS of $12500 \mathrm{mg} / \mathrm{L}$ and an oil content of $350 \mathrm{mg} / \mathrm{L}$. 
2. In the filtration of soil samples with the height of $9 \mathrm{~cm}$, the result obtained: DO levels of $0 \mathrm{mg} / \mathrm{L}$, BOD5 levels of $728.49 \mathrm{mg} / \mathrm{L}$, COD levels of $1939.36 \mathrm{mg} / \mathrm{L}$, TSS levels of $149.61 \mathrm{mg} / \mathrm{L}$, TDS amounting to $10920 \mathrm{mg} / \mathrm{L}$ and an oil content of $350 \mathrm{mg} / \mathrm{L}$.

3. In the filtration of soil samples with the height of $11 \mathrm{~cm}$, the result obtained: DO levels of $0 \mathrm{mg} / \mathrm{L}$, BOD5 levels of $545.25 \mathrm{mg} / \mathrm{L}$, COD levels of $1564.10 \mathrm{mg} / \mathrm{L}$, TSS levels of $139.82 \mathrm{mg} / \mathrm{L}$, TDS of $10110 \mathrm{mg} / \mathrm{L}$ and oil content of $340 \mathrm{mg} \mathrm{L}$.

Based on the Quality Standard of Waste Water for Business and/ or Domestic Activities according to Pergub Baku Mutu Lingkungan No.16, 2016 which refers to Peraturan Menteri Lingkungan Hidup No 5, 2014 concerning the Quality Standard of Wastewater, The I Class Standard of leachate used as an object the research has passed the permitted quality standard threshold, so it is not safe if it is released directly to the natural water sources because the soil has not been able to be a good filter. It is necessary to make some special treatment for leachate before it is discharged directly into the river or land.

\section{Conclusions}

The present study investigated the general characteristics, leachate and effect of soils in TPA Mandung Tabanan. Based on the USCS, AASHTO and Atteberg classification system the soil in TPA Mandung Tabanan is categorized into the clay. The leachate from the accumulation of solid can have some impact on the health and environment. This paper aims to study the general characteristic and leachate characteristic. Based on the USCS and AASTHO classification system the general characteristic of soils in TPA Mandung Tabanan is categorized into the clay. The leachate filtration was performed simultaneously with a hydraulic conductivity test simply varying its height from $7 \mathrm{~cm}, 9 \mathrm{~cm}$, and $11 \mathrm{~cm}$. The water drained from the hydraulic conductivity test has been re-examined to determine the changes in the leachate parameters after passing through the soil. The $\mathrm{K}$ value (hydraulic conductivity coefficient) in the soil hydraulic conductivity test sampled with height $11 \mathrm{~cm}, 9 \mathrm{~cm}, 7 \mathrm{~cm}$, were respectively $0.000050 \mathrm{~cm} / \mathrm{sec}, 0.000062 \mathrm{~cm} / \mathrm{sec}$, and $0.000065 \mathrm{~cm} / \mathrm{sec}$. The results showed a decrease in the coefficient of hydraulic conductivity along with the addition of leachate and the variation in sample height. The leachate in TPA Mandung before and after filtration had COD, BOD5, TSS, TDS and oil levels that exceeded the permitted threshold according to Regulation of Minister of Environment No. 5 of 2014 concerning Wastewater Quality Standard.

\section{References}

1. S. Renou, J.G. Givaudan, S. Poulain, F. Dirassouyan, P. Moulin. J. of Haz. Mat. 150, 3 (2008)

2. A.H. Robinson, Membrane Technology 2005, 6 (2005)

3. Sunarso. Lempung Kita yang Terlupakan 2. Available at: http://ppsdms.org (2007)

4. B. Das, Mekanika Tanah (Prinsip-prinsip Rekayasa Geoteknik) (Erlangga, Jakarta, 1995)

5. FAO. The Land Degradation Assessment in Drylands (LADA). Available at: http://www.fao.org/3/a-i3241e.pdf (2013)

6. I. Redana, Mekanika tanah (Udayana University Press, Denpasar, 2011)

7. Soemirat. Pencemaran air permukaan atau air tanah oleh air lindi. Available at: http://karlaherlina.blogspot.com/2013/07/pencemaran-air-permukaan-atau-airtanah_2788.html (1996) 